\title{
SUPEROXIDE DISMUTASE ISOENZYMES GENE EXPRESSION IN PERIPHERAL BLOOD MONONUCLEAR CELLS IN PATIENTS WITH CORONARY ARTERY DISEASE
}

\author{
GENSKA EKSPRESIJA IZOENZIMA SUPEROKSID DISMUTAZE U MONONUKLEARNIM \\ ĆELIJAMA PERIFERNE KRVI KOD PACIJENATA SA KORONARNOM ARTERIJSKOM BOLEŠĆU
}

\author{
Ana Ninić1, Nataša Bogavac-Stanojević1, Miron Sopić ${ }^{1}$, Jelena Munjas ${ }^{1}$, Jelena Kotur-Stevuljević ${ }^{1}$ \\ Milica Miljković ${ }^{1}$, Tamara Gojković ${ }^{1}$, Dimitra Kalimanovska-Oštrić ${ }^{2,3}$, Vesna Spasojević-Kalimanovska ${ }^{1}$ \\ ${ }^{1}$ Department for Medical Biochemistry, University of Belgrade - Faculty of Pharmacy, Belgrade, Serbia \\ ${ }^{2}$ Institute for Cardiovascular Diseases, Clinical Center of Serbia, Belgrade, Serbia \\ ${ }^{3}$ University of Belgrade - Faculty of Medicine, Belgrade, Serbia
}

\section{Summary}

Background: Coronary artery disease $(C A D)$ is one of the most important causes of mortality and morbidity in wide world population. Dyslipidemia, inflammation and oxidative stress may contribute to disruption of endothelium structure and function, atherosclerosis and CAD. Our study was aimed to determine whether $\mathrm{Cu} / \mathrm{Zn}$ superoxide dismutase ( $\mathrm{Cu} / \mathrm{Zn} \mathrm{SOD})$ and $\mathrm{Mn}$ superoxide dismutase ( $M n$ SOD) gene expression could be modulated by oxidative stress in CAD patients.

Methods: This study included 77 CAD patients and 31 apparently healthy persons. Serum lipid levels, high sensitivity C-reactive protein (hsCRP), total antioxidant status (TAS) and thiobarbituric acid-reacting substances (TBARS) were measured. SOD isoenzymes gene expression was determined in peripheral blood mononuclear cells using quantitative polymerase chain reaction.

Results: Mn SOD messenger ribonucleic acid (mRNA) levels were significantly lower in $C A D$ patients than in controls $(p=0.011)$, while $\mathrm{Cu} / \mathrm{Zn}$ SOD mRNA levels did not change significantly between tested groups $(p=0.091)$. We found significantly lower high-density lipoproteincholesterol $(H D L-c)(p<0.001)$ and TAS $(p<0.001)$ levels

\begin{abstract}
Kratak sadržaj
Uvod: Koronarna arterijska bolest (KAB) je jedan od najvažnijih uzročnika mortaliteta i morbiditeta u širokoj svetskoj populaciji. Dislipidemija, inflamacija i oksidativni stres mogu doprineti poremecaju strukture i funkcije endotela, nastanku ateroskleroze i KAB. Naša studija je imala za cilj da utvrdi da li ekspresije gena $\mathrm{Cu} / \mathrm{Zn}$ supsoksid dismutaze (Cu/Zn SOD) i Mn superoksid dismutaze (Mn SOD) mogu da budu promenjene pod uticajem oksidativnog stresa kod pacijenata sa KAB.

Metode: Ova studija je obuhvatila 77 pacijenata sa KAB i 31 naizgled zdravih osoba kod kojih su određeni nivoi serumskih lipida, visoko osetljivi C-reaktivni protein (hsCRP), ukupni antioksidativni status (TAS) i tiobarbituratna kiselina-reagujuće supstance (TBKRS). Ekspresija gena izoenzima SOD određena je u mononuklearnim ćelijama periferne krvi pomoću metode kvantitativne lančane reakcije polimeraze.

Rezultati: Nivoi informacione ribonukleinske kiseline (iRNK) Mn SOD su značajno bili niži kod pacijenata sa KAB nego kod kontrole $(p=0,011)$, dok se nivoi $\mathrm{Cu} / \mathrm{Zn}$ SOD iRNK nisu značajno razlikovali između ispitanih grupa $(p=0,091)$. Kod pacijenata sa KAB utvrđeni su znatno niži
\end{abstract}

\section{Address for correspondence:}

Ana Ninić, PhD Pharm

Assistant professor

Department for Medical Biochemistry

University of Belgrade - Faculty of Pharmacy

Vojvode Stepe 450, 11000 Belgrade, Serbia

Phone: +381113951266

Fax: +381113972840

e-mail: aninic@pharmacy.bg.ac.rs
List of abbreviations: CAD, Coronary artery disease; ROS, reactive oxygen species; TC, total cholesterol; LDL-C, low-density lipoprotein cholesterol; TG, triglyceride; HDL-c, high-density lipoprotein cholesterol; DNA, deoxyribonucleic acid; SOD, superoxide dismutase; EC SOD, extracellular superoxide dismutase; $\mathrm{O}_{2}{ }^{-1}$ superoxide anion radical; $\mathrm{H}_{2} \mathrm{O}_{2}$, hydrogen peroxide; TAS, total antioxidative status; mRNA, messenger ribonucleic acid; $A C S$, acute coronary syndrome; $A C E$, angiotensin-converting-enzyme; PBMC, peripheral blood mononuclear cells; EDTA, ethylenediaminotetraacetic acid; hsCRP, high sensitive $\mathrm{C}$-reactive protein; TBARS, thiobarbiturate acid-reactive substances; PCR, polymerase chain reaction 
and significantly higher hsCRP $(p=0.002)$ and TBARS $(p<0.001)$ in CAD patients than in controls. There were significant positive correlations between TAS and Mn SOD mRNA $(\rho=0.243, p=0.020)$ and TAS and $\mathrm{Cu} / \mathrm{Zn}$ SOD mRNA $(\rho=0.359, p<0.001)$. TBARS negatively correlated only with $\mathrm{Cu} / \mathrm{Zn}$ SOD mRNA $(\rho=-0.215, p=0.040)$. TAS levels remained independent predictor for Mn SOD mRNA levels $(O R=2.995, p=0.034)$.

Conclusions: Results of this study showed that Mn SOD gene expression were decreased in CAD patients compared to controls and can be modulated by nonenzymatic antioxidant status in blood.

Keywords: CAD, oxidative stress, $\mathrm{Cu} / \mathrm{Zn}$ SOD, Mn SOD, qPCR

\section{Introduction}

Coronary artery disease (CAD) is one of the leading causes of morbidity and mortality in the world (1). Atherosclerosis, as chronic inflammatory, fibroproliferative disease of the large and middle-sized arteries is the essential for onset and development of CAD (2). Dyslipidemia, chronic low-grade inflammation and the imbalance between the production of reactive oxygen species (ROS) and enzymatic and non-enzymatic antioxidant protection could cause endothelial dysfunction of coronary arteries (3-5). Increased total cholesterol (TC) concentrations, especially low-density lipoprotein cholesterol (LDL-c), high triglyceride (TG) and low high-density lipoprotein cholesterol (HDL-c) levels in plasma, are unique factors that are sufficient to lead to atherosclerosis development (4). Hyperlipidemia stimulates the proinflammatory monocytes to migrate to atherosclerotic lesions where they synthesize large amounts of cytokines and other proinflammatory mediators. Modified lipoproteins interact with scavenger receptors and induce proinflammatory signals within macrophages and foam cells formation $(2,5)$.

Disregulation of free radical signal pathways can, also, lead to the initiation and progression of atherosclerosis $(3,6)$. ROS cause damage to deoxyribonucleic acid (DNA), protein modification and the lipid peroxides generation which play a role in atherogenesis (3). The most important role in the first defense line of ROS have enzymes of antioxidant protection, especially enzyme superoxide dismutase (SOD) found in the form of three isoenzymes: $\mathrm{Cu} / \mathrm{Zn}$ SOD, Mn SOD and extracellular SOD (EC SOD) in various tissues of the organism $(7,8)$. SOD catalyzes dismutation of superoxide anion radical $\left(\mathrm{O}_{2}{ }^{-}\right)$to hydrogen peroxide $\left(\mathrm{H}_{2} \mathrm{O}_{2}\right)$. Throught antioxidative and anti-apoptotic capacities and by inhibiton of cell migration and hypertrophy, SOD isoenzymes exert potential protective roles against atherosclerosis occurence $(9,10)$. On the other hand, disturbance in their messenger ribonucleic acid (mRNA) levels could nivoi holesterola u lipoproteinima visoke gustine (HDL-h) $(p<0,001)$ i TAS $(p<0,001)$ i znatno veće koncentracije hsCRP $(p=0,002)$ i TBKRS $(p<0,001)$. Postojale su značajne pozitivne korelacije između TAS i iRNK Mn SOD $(\rho=0,243, p=0,020)$ i TAS i iRNK Cu/Zn SOD $(\rho=$ $0,359, p<0,001)$. TBKRS su bile u negativnoj korelaciji samo sa iRNK Cu/Zn SOD ( $\rho=-0,215, p=0,040)$. TAS je bio nezavisni prediktor za nivoe iRNK Mn SOD $(O R=2,995$, $\mathrm{p}=0,034)$.

Zaključak: Rezultati ove studije pokazali su da je ekspresija Mn SOD gena smanjena kod pacijenata sa KAB u poređenju sa kontrolnom grupom i da može biti modulirana neenzimskim antioksidativnim statusom u krvi.

Ključne reči: $K A B$, oksidativni stres, $C u / Z n$ SOD, $M n$ SOD, kvantitativni PCR

lead to cellular component damage induced by oxidative stress. In addition to enzymatic antioxidant protection, non-enzymatic antioxidant molecules given as total antioxidative status (TAS) present in the serum (proteins, urea, creatinine, bilirubin, uric acid, vitamin $C$, vitamin $E$, reduced glutathione, lipoic acid, $\beta$-carotene and others) plays a significant role in the defense against ROS (11).

The aim of this study was to determine which of the SOD isoenzyme gene expression was significantly different in CAD patients compared to controls, whether they could be modulated by oxidative stress and antioxidative defence markers.

\section{Materials and Methods}

\section{Study population}

This study included 77 CAD patients (36 men and 41 women) $52.12 \pm 10.97$ years of age and 31 apparently healthy persons (13 men and 18 women) $45.3 \pm 9.0$ years of age. CAD patients were recruited from the Institute for Cardiovascular Diseases, Clinical Centre of Serbia. All patients were subjected to coronary angiography to assess the severity of coronary disease. Indications for this invasive diagnosis were: stable angina pectoris, unstable angina pectoris, post-ischemic revascularization, myocardial infarction or atypical chest pain with a positive history of cardiovascular disease family disorders, cardiac insufficiency, valvulopathy and non-specific symptoms (asthenia, syncope and dyspnea). Significant stenosis, defined as a decrease in lumen greater than or equal to $50 \%$ in at least one of the three main coronary blood vessels, was diagnosed in 32 patients.

Acute coronary syndrome (ACS) which included unstable angina pectoris and acute infarction myocardium with or without ST elevation were diagnosed in 30 patients. 
All of 77 patients were on some form of therapy before angiography procedure: 17 on beta blockers, 23 on beta-blockers and angiotensin-convertingenzyme (ACE) inhibitors, 16 on ACE inhibitors and diuretics and 21 on beta-blockers, ACE inhibitors and diuretics. Also, 31 out of 77 were on statin therapy.

Apparently healthy persons formed a control group after checking their health status by physician based on the determination of basic biochemical parameters, lipid status, demographic data (blood pressure, smoking status, family history of cardiovascular, renal and other diseases and possible usage of medicines) and intima media thickness measurement of both carotid arteries. Prior enrollment in this study, these persons were not diagnosed cardiovascular disease or other illness that led to its development.

Patients with hypertension, diabetes mellitus, hypertriglyceridemia and chronic renal failure were excluded from the control group.

After being thoroughly informed about the objectives, procedures and risks of participation all examinees gave consent for voluntary participation in a study which was planned in accordance with ethical principles established in the Helsinki Declaration and approved by the Ethical Committee of the University of Belgrade - Faculty of Pharmacy.

\section{Blood sampling and laboratory analyses}

After adequate preparation of the participants, three blood samples were taken from the front cubital vein using vacutainers with ethylenediaminotetraacetic acid (EDTA) systems for plasma and peripheral blood mononuclear cells - PBMC (lymphocytes and monocytes) isolation and vacutainers with serum separator gel for serum separation. Plasma and serum were separated by centrifugation for 10 minutes at $3000 \mathrm{rpm}$, divided into aliquots and stored at $-80{ }^{\circ} \mathrm{C}$ until analysis. Blood samples with EDTA anticoagulant for RNA isolation were used to separate lymphocytes and monocytes from other blood cells, which were then suspended in $1 \mathrm{~mL}$ of TRIzol $^{\circledR}$ reagent (Invitrogen Life Technologies, Foster City, CA, USA) and frozen at $-80^{\circ} \mathrm{C}$ until RNA isolation.

Lipid status parameters (TC, HDL-C and TG) and glucose were measured on the ILab 300+ (Instrumentation Laboratory, Milano, Italy) by Biosystems SA (Barcelona, Spain) and Bioanalytica (Belgrade, Serbia) tests using enzymatic methods. LDL-c was calculated using the Friedwald formula (12). High sensitive $\mathrm{C}$-reactive protein ( $\mathrm{hs} C \mathrm{RP}$ ) concentration was determined on the biochemical analyzer COBAS ${ }^{\circledR}$ c6000-Roche Diagnostics using immunoturbidimetric method (Rosche, Mannheim, Germany).

Total antioxidant status (TAS) was measured as absorbance reduction of the ABTS * $+\left[2,2^{\prime}\right.$-azinobis (3-ethylbenzothiazoline-6-sulfonic acid) cationic acid] in the presence of antioxidants (13). Thiobarbiturate acid-reactive substances (TBARS) were determined spectrophotometrically on the principle where thiobarbituric acid reacts with the lipid peroxidation end products creating a colored complex (14).

\section{RNA isolation and Real-time PCR method}

PBMC were isolated on the Ficoll-Paque PLUS gradient-gel (GE Healthcare, Wisconsin, USA) according to the manufacturer's instructions and suspended in $1 \mathrm{~mL}$ TRIzol ${ }^{\circledR}$ reagent. The RNA was isolated using modified classic RNA isolation protocol, described by Chomczynski et al. (15) and optimized for the laboratory conditions of the Department for Medical Biochemistry, University of Belgrade - Faculty of Pharmacy (16). Reverse transcription and real-time polymerase chain reaction (qPCR) experiments were performed on the 7500 Real-Time PCR System (Applied Biosystems, Foster City, CA, USA). Cu/Zn SOD and Mn SOD gene expression (mRNA) levels were measured using the TaqMan ${ }^{\circledR}$ Gene Expression Assays (Applied Biosystems, Foster City, USA) according to the manufacturer's instructions. Gene expression data were expressed as a ratio between target gene and endogenous control ( $\beta$-actin) mRNA: Normalised $\mathrm{Cu} / \mathrm{Zn}$ SOD mRNA levels $=\mathrm{Cu} / \mathrm{Zn}$ SOD mRNA $/ \beta-$ actin mRNA; normalised Mn SOD mRNA levels = $\mathrm{Mn}$ SOD mRNA/ $\beta$-actin mRNA. Negative controls for reverse transcription (no reverse transcriptase) and non-template controls (no complementary DNA) were included in the experiments.

\section{Statistical analysis}

After testing data distributions with Shapiro-Wilk test, continuous data were expressed as mean \pm standard deviation for normally distributed data and median (interquartile range) for skewed distributed data. Comparisons were made by Student $t$-test, Man Whitney $U$ test and Kruskal-Wallis test depending on the type of data distribution. Categorical variables were given as absolute frequencies and compared with Chi-square test for contingency tables where appropriate. Bivariate Spearman analysis was used to test the correlations between normalised $\mathrm{Cu} / \mathrm{Zn}$ SOD and $M n$ SOD mRNA levels and clinical markers. Ordinal regression analysis was performed to assess the associations and predictions of oxidative stress and antioxidative defence markers on $\mathrm{Cu} / \mathrm{Zn} \mathrm{SOD}$ and $M n S O D$ mRNA levels. The dependent variables were $\mathrm{Cu} / \mathrm{Zn}$ SOD and Mn SOD mRNA levels ranked by terciles. In multivariate ordinal regression analysis independent variables were continuous and categorical variables which showed to be significantly different between tested groups. In ordinal regression analysis the assumption of proportional odds and multicollinearity among independent variables were 
tested. Data from those analyses were presented as odds ratio and 95\% confidence interval $(\mathrm{Cl})$. Statistical power of the study was also calculated. P values less than 0.05 were considered statistically significant. Statistical analyses were carried out using IBM ${ }^{\circledR}$ SPSS $^{\circledR}$ Statistics version 22 software (Chicago, USA).

\section{Results}

There were no significant differences in any of clinical and gene expression markers between patients with and without significant stenosis and between patients with and without ACS and because of that all the patients were analysed together forming CAD group.

The baseline demographic data of the study populations are summarized in Table $I$.

CAD patients were significantly older and had higher BMI than controls. Dyastolic blood pressure was lower in CAD patients than in controls. The study groups did not differ in gender distribution, smoking status and systolic blood pressure.

CAD patients had higher glucose and hsCRP, but lower HDL-c concentration than controls (Table II). CAD patients were in the state of oxidative stress. They had higher TBARS levels but lower TAS and Mn SOD mRNA levels than controls (Table II).

Correlation analysis revealed significant positive correlations between TAS and both examined gene expression levels, $\mathrm{Cu} / \mathrm{Zn}$ SOD mRNA and Mn SOD
mRNA levels $(\rho=0.359, p<0.001$ and $\rho=0.243$, $\mathrm{p}=0.020$, respectively). Cu/Zn SOD mRNA levels correlated negatively with TBARS (Table III).

Associations between normalised mRNA SOD isoenzymes levels and oxidative stress status markers were tested by ordinal regression analysis. Either in univariate or multivariate ordinal regression analyses normalised $\mathrm{Cu} / \mathrm{Zn}$ SOD mRNA levels showed no significant associations neither with TAS nor TBARS (Table IV).

In univariate ordinal regression analysis, TAS was showed to be associated with Mn SOD mRNA levels (Table $V$ ). This analysis indicated when TAS rose for $1 \mathrm{mmol} / \mathrm{L}$, the probability for higher $\mathrm{Mn}$ SOD mRNA levels increased 1.852 times $(O R=1.852$, $p=0.040$ ).

Independent variable which showed to be significantly different between patients and controls (Tables I and II) showing no multicollinearity were included in multivariate ordinal regression analysis (Table V). This statistical analysis showed independent associations and predictions of TAS on $\mathrm{Mn}$ SOD mRNA levels. Adjusted odds for TAS given in the Model $(O R=2.995, p=0.034)$, demonstrated that rise in TAS by $1 \mathrm{mmol} / \mathrm{L}$ increased the probability for higher Mn SOD mRNA levels almost 3 times. Nagelkerke $\mathrm{R}^{2}$ for the Model was 0.186 indicated that $18.6 \%$ variation in Mn SOD mRNA levels could be explained by this Model (Table V).

Observed statistical power of our study based on univariate logistic regression analysis for odds ratio of

Table I General data of the tested populations.

\begin{tabular}{|c|c|c|c|}
\hline & Control group & CAD patients & $\mathrm{p}$ \\
\hline Examinees, N (male/female) & $31(13 / 18)$ & $77(36 / 41)$ & 0.649 \\
\hline Ages, years & $45.72 \pm 8.97$ & $52.12 \pm 10.97$ & 0.004 \\
\hline $\mathrm{BMI}, \mathrm{kg} / \mathrm{m}^{2}$ & $24.97 \pm 3.80$ & $26.63 \pm 3.92$ & 0.039 \\
\hline Systolic blood pressure, $\mathrm{mmHg}^{*}$ & $130(115-137)$ & $120(110-130)$ & 0.056 \\
\hline Diastolic blood pressure, $\mathrm{mmHg}^{*}$ & $88(75-92)$ & $80(70-80)$ & 0.002 \\
\hline $\begin{array}{l}\text { Antihypertensive therapy: } \\
\text { Beta-blockers/beta-blockers and ACE inhibitors/ACE } \\
\text { inhibitors and diuretics/ } \\
\text { beta-blockers, ACE inhibitors and diuretics }\end{array}$ & $0 / 0 / 0 / 0$ & $17 / 23 / 16 / 21$ & / \\
\hline Statin therapy, yes/no & $0 / 0$ & $31 / 46$ & / \\
\hline Smoking status (smokers/non-smokers)\# & $11 / 20$ & $24 / 53$ & 0.665 \\
\hline
\end{tabular}

Data are given as arithmetic mean \pm standard deviation and compared by Student $t$-test.

* Skewed distributed data are given as median (interquartile range) and compared by Mann-Whitney test.

\# Categorical data are given as absolute frequencies and compared by Chi-square test for contingency tables. 
Table II Clinical data of studied populations.

\begin{tabular}{|l|c|c|c|}
\hline & Control group & CAD patients & P \\
\hline Glucose, $\mathrm{mmol} / \mathrm{L}$ & $5.10(4.82-5.39)$ & $5.30(4.80-5.80)$ & 0.027 \\
\hline Total cholesterol, mmol/L & $4.80(4.50-5.82)$ & $4.66(4.05-5.80)$ & 0.171 \\
\hline $\mathrm{HDL}-\mathrm{c}, \mathrm{mmol} / \mathrm{L}$ & $1.53(1.33-1.81)$ & $1.17(0.92-1.42)$ & $<0.001$ \\
\hline $\mathrm{LDL}-\mathrm{c}, \mathrm{mmol} / \mathrm{L}$ & $2.91(2.52-3.69)$ & $2.80(2.37-3.61)$ & 0.308 \\
\hline TG, mmol/L & $1.29(0.99-1.73)$ & $1.43(1.12-1.81)$ & 0.150 \\
\hline hsCRP, mg/L & $1.16(0.61-1.87)$ & $2.32(1.12-5.35)$ & 0.002 \\
\hline TAS, mmol/L* & $1.14 \pm 0.126$ & $0.84 \pm 0.21$ & $<0.001$ \\
\hline TBARS, $\mu \mathrm{mol} / \mathrm{L}$ & $0.44(0.33-0.62)$ & $1.13(0.82-1.26)$ & $<0.001$ \\
\hline Normalised mRNA Cu/Zn SOD levels & $0.84(0.71-0.95)$ & $0.88(0.75-1.13)$ & 0.094 \\
\hline Normalised mRNA Mn SOD levels & $1.02(0.84-1.13)$ & $0.86(0.72-1.03)$ & 0.011 \\
\hline
\end{tabular}

Data are presented as median (interquartile range) and compared by Mann-Whitney test.

* Data are given as arithmetic mean \pm standard deviation and compared by Student t-test.

Table III Correlation coefficients of normalised Cu/Zn SOD and Mn SOD mRNA levels with clinical markers in tested populations.

\begin{tabular}{|c|c|c|c|c|}
\hline \multirow[t]{2}{*}{ Parameter } & \multicolumn{2}{|c|}{$\begin{array}{c}\text { Normalised mRNA Cu/Zn } \\
\text { SOD levels }\end{array}$} & \multicolumn{2}{|c|}{$\begin{array}{l}\text { Normalised mRNA Mn } \\
\text { SOD levels }\end{array}$} \\
\hline & $\rho$ & $\mathrm{p}$ & $\rho$ & $\mathrm{p}$ \\
\hline Ages, years & -0.011 & 0.916 & 0 & 0.997 \\
\hline BMI, $\mathrm{kg} / \mathrm{m}^{2}$ & -0.092 & 0.371 & -0.128 & 0.193 \\
\hline Systolic blood pressure, $\mathrm{mmHg}$ & -0.125 & 0.226 & -0.142 & 0.147 \\
\hline Diastolic blood pressure, $\mathrm{mmHg}$ & 0.022 & 0.830 & 0.019 & 0.850 \\
\hline Glucose, mmol/L & -0.098 & 0.341 & -0.163 & 0.094 \\
\hline Total cholesterol, mmol/L & -0.036 & 0.727 & -0.111 & 0.256 \\
\hline HDL-c, mmol/L & 0.106 & 0.305 & -0.028 & 0.772 \\
\hline LDL-c, mmol/L & -0.023 & 0.828 & -0.038 & 0.698 \\
\hline TG, mmol/L & -0.108 & 0.294 & -0.155 & 0.113 \\
\hline hsCRP, mg/L & -0.155 & 0.157 & -0.019 & 0.856 \\
\hline TAS, mmol/L & 0.359 & $<0.001$ & 0.243 & 0.020 \\
\hline TBARS, $\mu \mathrm{mol} / \mathrm{L}$ & -0.215 & 0.040 & -0.079 & 0.627 \\
\hline
\end{tabular}


Table IV Estimated odds ratios after ordinal regression analysis for normalised $\mathrm{Cu} / \mathrm{Zn}$ SOD mRNA levels prediction.

\begin{tabular}{|c|c|c|c|}
\hline & \multicolumn{2}{|c|}{ Unadjusted } & \\
\hline & OR $(95 \% \mathrm{Cl})$ & $\mathrm{p}$ & Nagelkerke $\mathrm{R}^{2}$ \\
\hline $\begin{array}{l}\text { TAS, } \\
\mathrm{mmol} / \mathrm{L}\end{array}$ & $\begin{array}{c}0.484 \\
(0.124-1.927)\end{array}$ & 0.306 & 0.015 \\
\hline \multirow[t]{2}{*}{$\begin{array}{l}\text { TBARS, } \\
\mu \mathrm{mol} / \mathrm{L}\end{array}$} & $\begin{array}{c}0.970 \\
(0.486-1.939)\end{array}$ & 0.993 & 0.001 \\
\hline & \multicolumn{2}{|l|}{ Adjusted } & \\
\hline Model & OR $(95 \% \mathrm{Cl})$ & $\mathrm{p}$ & Nagelkerke $\mathrm{R}^{2}$ \\
\hline $\begin{array}{l}\text { TAS, } \\
\mathrm{mmol} / \mathrm{L}\end{array}$ & $\begin{array}{c}2.562 \\
(0.237-27.755)\end{array}$ & 0.439 & \multirow{2}{*}{0.163} \\
\hline $\begin{array}{l}\text { TBARS, } \\
\mu \mathrm{mol} / \mathrm{L}\end{array}$ & $\begin{array}{c}0.371 \\
(0.130-1.055)\end{array}$ & 0.063 & \\
\hline
\end{tabular}

Analysis was performed after bootstrap for 10000 permutations. Model included categorical variables: statin and antihypertensive therapies and continuous variables: ages, BMI, glucose, HDL-c, hsCRP, TAS and TBARS.

Table V Estimated odds ratios after ordinal regression analysis for normalised Mn SOD mRNA levels prediction.

\begin{tabular}{|c|c|c|c|}
\hline & \multicolumn{2}{|c|}{ Unadjusted } & \\
\hline & OR $(95 \% \mathrm{Cl})$ & $\mathrm{p}$ & Nagelkerke $\mathrm{R}^{2}$ \\
\hline TAS, mmol/L & $\begin{array}{c}1.852 \\
(1.439-2.211)\end{array}$ & 0.040 & 0.034 \\
\hline \multirow[t]{2}{*}{ TBARS, $\mu \mathrm{mol} / \mathrm{L}$} & $\begin{array}{c}0.595 \\
(0.269-1.342)\end{array}$ & 0.212 & 0.010 \\
\hline & \multicolumn{2}{|l|}{ Adjusted } & \\
\hline Model & OR $(95 \% \mathrm{Cl})$ & $\mathrm{p}$ & Nagelkerke $\mathrm{R}^{2}$ \\
\hline TAS, $\mathrm{mmol} / \mathrm{L}$ & $\begin{array}{c}2.995 \\
(0.222-5.755)\end{array}$ & 0.034 & \multirow{2}{*}{0.186} \\
\hline TBARS, $\mu \mathrm{mol} / \mathrm{L}$ & $\begin{array}{c}2.403 \\
(0.868-6.659)\end{array}$ & 0.134 & \\
\hline
\end{tabular}

Analysis was performed after bootstrap for 10000 permutations. Model included categorical variables: statin and antihypertensive therapies and continuous variables: ages, BMI, glucose, HDL-c, hsCRP, TAS and TBARS.

1.852, probability level of 0.05 and the sample size of 108 subjects was 0.80 . Observed statistical power of our study based on multiple logistic regression analysis for odds ratio of 2.995 , probability level of 0.05 and the sample size of 108 subjects was 0.95 .

\section{Discussion}

Cardiovascular diseases have been on the top of major causes of disease, disability and premature mortality (before age 65) in developed and developing countries for decades now (1). The new era in the study of cardiovascular diseases encompasses the role of the oxidation process in their pathogenesis. Studies indicate that ROSs are significant participants in a wide range of diseases such as hypertension, arrhythmias, myocardial infarction, and heart failure $(3,17)$.

In our group of CAD patients, TBARS concentration was significantly higher than in the control group (Table II) indicating active lipid peroxidation in CAD patients. Of many biomolecules in the body, lipids, especially those with unsaturated bonds, are easily and quickly subjected to oxidation. The main product of lipid peroxidation is TBARS, which can further lead to the formation of other free radicals and can react with DNA and proteins expressing mutagenic and proatherogenic effects (18). Also, in CAD patients there was an evident significant weakening of non-enzymatic antioxidant protection. TAS levels were significantly lower in CAD patients than in the control group. Many biomolecules in serum (proteins, urea, creatinine, bilirubin, uric acid, vitamin $C$, vitamin $E$, reduced glutathione, lipoic acid, $\beta$-carotene and others) have antioxidant properties and measurement of TAS is a convenient and useful tool to determine total antioxidative capacity of an organism (13). Also, significantly higher chronic low-grade inflammation was evident in CAD patients (Table II). Numerous prospective studies have shown that CRP concentrations less than $5 \mathrm{mg} / \mathrm{L}$ are associated with the higher risk for CAD development and can predict the outcomes of acute myocardial infarction, stroke and peripheral arterial disease $(19,20)$. Significantly higher hsCRP levels in our patients could indicate higher risk for unfavorable CAD progression. Our results are in an agreement with the previous findings showing a disturbed balance between prooxidants and antioxidants and the presence of low-grade inflammation in CAD patients $(6,9,10,19,21)$.

Beside non-enzymatic antioxidants, the main role in cellular antioxidant protection against $\mathrm{O}_{2}{ }^{-}$. have SOD isoenzymes, cytoplasmatic $\mathrm{Cu} / \mathrm{Zn}$ SOD and mitochondrial Mn SOD $(10,17)$. Cu/Zn SOD mRNA levels did not differ between tested groups, while Mn SOD mRNA levels were significantly lower in CAD patients than in controls (Table II). Furthermore, Mn SOD mRNA levels correlated positively with TAS levels $(\rho=0.243, p=0.020)$ (Table III). Ordinal regression analysis revealed that TAS levels were independently associated with Mn SOD mRNA levels in PBMC (Table V). According to these results, mitochondrial antioxidative protection of PBMC was exhausted in CAD patients and could be determined by plasma TAS.

However, there are not many studies that have investigated gene expression of two intracellular SOD isoenzymes in humans. The most important and most 
studied is EC SOD due to its higher presence in the vascular endothelium, smooth muscle, connective tissue and blood (8). Since EC SOD is not expressed in PBMC, its mRNA levels have not been analyzed in this study. However, our findings were in line with gene expression studies of Abdullah et al. (20) and Infante et al. (22) showing down regulation of $\mathrm{Mn}$ SOD gene in PBMC of CAD patients. Mn SOD mRNA levels have been identified as one of three genes having significant role in the pathogenesis and progression of CAD (20). It was proposed to be a potential biomarker candidate for CAD because its levels were consistently down regulated in PBMC of CAD patients (20). Excess production of ROS and/or down regulation of $\mathrm{MnSOD}$ could reduce nitric oxide production leading to endothelial dysfunction and atherosclerosis progression $(3,24)$. On the other hand, our results were partially in the agreement with Dieterich and colleagues (23). In their study, $\mathrm{Cu} / \mathrm{Zn}$ SOD and Mn SOD mRNA levels, as well as their protein concentrations, were unchanged in the heart of patients with heart failure compared to those without it. From all tested intracellular enzymes in the heart, only catalase gene expression and activity have been increased (23). They concluded that in the heart of patients with the final stage of heart failure, the antioxidant reserve was not weakened and, consequently, in the pathogenesis of this disease, antioxidant protection enzyme has no significant role in the heart. Their results were opposite to results obtained in experimental animals, in which the gene expression of these same antioxidant enzymes was reduced $(24,25)$. As well in study by Khaper et al. (26), one week after acute myocardial infarction, SOD isoenzymes mRNA levels were reduced by $40 \%$ compared to pre-attack but were similar to those in healthy subjects. However, sixteen weeks after acute attack, SOD isoenzyme levels were reduced by $73 \%$

\section{References}

1. Benjamin E, Blaha M, Chiuve S, Cushman M, Das S, Deo $R$, et al. Heart Disease and Stroke Statistics - 2017 Update: A Report From the American Heart Association. Circulation 2017: 135; e146-e603.

2. Hansson G. Inflammation, atherosclerosis, and coronary artery disease. N Engl J Med 2005; 352: 1685-95.

3. Sinatra S, Demarco J. Free radicals, oxidative stress, oxidized low density lipoprotein (LDL), and the heart: antioxidants and other strategies to limit cardiovascular damage. Conn Med 1995; 59: 579-88.

4. Martin M, Hulley S, Browner W, Kuller L, Wentworth D. Serum cholesterol, blood pressure, and mortality: implications from a cohort of 361,662 men. Lancet 1986; 25: 933-36.

5. Turcato G, Cervellin G, Bonora A, Prati D, Zorzi E, Ricci G, Salvagno LG, Maccagnani A, Lippi G. Red blood cell compared to levels in healthy subjects. In our study we did not determine either SOD isoenzymes concentration or activities, but we can assume they were lower in CAD patients compared to controls as an indicator of exhausted enzymatic antioxidative protection, the same as for TAS.

We have recognized several limitations of our study. Firstly, the number of patients and controls was small. Secondly, this study included patients from a single medical institution. Accordingly, more studies in larger groups are needed. Thirdly, Cu/Zn SOD and $\mathrm{Mn}$ SOD activities or concentrations were not determined in plasma because they does not necessarily need to be in correlation with gene expression in PBMC.

Despite these limitations, we hope that our research give significant contribution about $\mathrm{Cu} / \mathrm{Zn}$ SOD and Mn SOD gene regulation in PBMC of CAD patients. Our results confirm the previous scientific knowledge that Mn SOD mRNA levels could serve as a potential biomarker for CAD. Yet, this is the first study which has demonstrated independent associations and prediction of blood TAS levels on $\mathrm{Mn}$ SOD mRNA levels in PBMC of CAD. Regardless, this needs to be confirmed in larger cohort of CAD patients.

Acknowledgement. The work was financially supported by the Ministry of Education, Science and Technological Development, Republic of Serbia (Project No. 175035) and COST ACTION CliniMARK CA16113.

\section{Conflict of interest statement}

The authors declare that they have no conflicts of interest.

distribution width improves reclassification of patients admitted to the emergency department with acute decompensated heart failure. J Med Beiochem 2018; 37: 299-306.

6. Kunsch C, Medford R. Oxidative stress as a regulator of gene expression in the vasculature. Circ Res 1999; 85: 753-66.

7. Fridovich I. Superoxide radical and superoxide dismutases. Annu Rev Biochem 1995; 64: 97-112.

8. Marklund S, Holme E, Hellner L. Superoxide dismutase in extracellular fluids. Clin Chim Acta 1982; 126: 41-51.

9. Madamanchi N, Moon S, Hakim Z, Clark S, Mehrizi A, Patterson C, Runge M. Differential activation of mitogenic signaling pathways in aortic smooth muscle cells deficient in superoxide dismutase isoforms. Arterioscler Thromb Vasc Biol 2005; 25: 950-6. 
10. Peng J, Lu T, Chang H, Ge X, Huang B, Li W. Elevated Levels of Plasma Superoxide Dismutases 1 and 2 in Patients with Coronary Artery Disease. Biomed Res Int 2016; 2016: 3708905.

11. Rice-Evans C, Miller N. Total antioxidant status in plasma and body fluids. Methods Enzymol 1994; 234: 279-93.

12. Friedewald W, Levy R, Fredrickson D. Estimation of the concentration of low-density lipoprotein cholesterol in plasma, without use of the preparative ultracentrifuge. Clin Chem 1972; 18: 499-502.

13. Erel O. A novel automated direct measurement method for total antioxidant capacity using a new generation, more stable ABTS radical cation. Clin Biochem 2004; 37: 277-85.

14. Girotti M, Khan N, McLellan B. Early measurement of systemic lipid peroxidation products in plasma of major blunt trauma patient. J Trauma 1991; 31: 32-5.

15. Chomczynski, P. A reagent for the single-step simultaneous isolation of RNA, DNA and proteins from cell and tissue samples. BioTechniques 1993: 15; 532-7.

16. Vujovic A, Spasojevic-Kalimanovska V, Bogavac-Stanojevic N, Spasic S, Kotur-Stevuljevic J, Jelić-lvanović Z. Comparison of two RNA isolation methods for determination of SOD1 and SOD2 gene expression in human blood and mononuclear cells. Indian J Biotechnol 2013; 12: 468-74.

17. Hoeschen R. Oxidative stress and cardiovascular disease. Can J Cardiol 1997; 13: 1021-25.

18. Ghaffarzadeh $M$, Ghaedi $H$, Alipoor B, Omrani DM Kazerouni F, Shanaki M, Labbaf A, Pashaiefar H, Rahimipour A. Association of miR-149 (RS2292832) variant with the risk of coronary artery disease. J Med Biochem 2017; 36: 251-8.
19. Shrivastava A, Singh H, Raizada A, Singh S. C-reactive protein, inflammation and coronary heart disease. The Egyptian Heart Journal 2015; 67: 89-97.

20. Abdullah M, Othman Z, Noor H, Arshad S, Yusof A, Jamal $R$, et al. Peripheral blood gene expression profle of atherosclerotic coronary artery disease in patients of di erent ethnicity in Malaysia. J Cardiol 2012; 60: 192203.

21. Wronska-Nofer T, Nofer J, Stetkiewicz J, Wierzbicka $M$, Bolinska $\mathrm{H}$, Fobker $M$, et al. Evidence for oxidative stress at elevated plasma thiol levels in chronic exposure to carbon disulfide (CS2) and coronary heart disease. Nutr Metab Cardiovas 2007; 17: 546-53.

22. Infante T, Forte $E$, Aiello M, Salvatore M, Cavaliere C. In Vivo and In Vitro analysis in coronary artery Disease related to Type 2 Diabetes. Front Endocrinol 2017: 8: 209.

23. Dieterich S, Bieligk U, Beulich K, Hasenfuss G, Prestle J. Gene expression of antioxidative enzymes in the human heart: increased expression of catalase in the end-stage failing heart. Circulation 2000; 101: 33-9.

24. Haramaki N, Stewart D, Aggarwal S, Ikeda H, Reznick A, Packer L. Networking antioxidants in the isolated rat heart are selectively depleted by ischemia - reperfusion. Free Radic Biol Med 1998; 25: 329-39.

25. Lin C, Liu C, Sun Y, Chang L, Chiu Y, Huang S, et al. Alteration of endogenous antioxidant enzymes in naturally occurring hypertrophic cardiomyopathy. Biochem Mol Biol Int 1997; 43: 1253-63.

26. Khaper N, Kaur K, Li T, Farahmand F, Singal P. Antioxidant enzyme gene expression in congestive heart failure following myocardial infarction. Mol Cell Biochem 2003; 251: 9-15. 